Annals of the University of Craiova

The Chemistry Series

Volume XLVII, No. 2 (2021) 83-92

homepage: chimie.ucv.ro/anale/

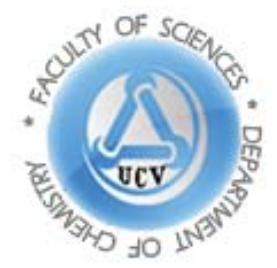

\title{
Iron sulfide phases: A brief review
}

\section{Review article}

\section{Elena Cristina Cârstea ${ }^{1 *}$ Paul Chiriță ${ }^{1}$}

${ }^{1}$ University of Craiova, Faculty of Sciences, Department of Chemistry, Calea București 107i, Craiova, Romania

*E-mail: carstea.elena.p4c@student.ucv.ro

Received: 10.10.2021 / Accepted: 20.11.2021 / Published: 27.12.2021

\begin{abstract}
This short review collects information seen as important for understanding the behavior of iron sulfides. One presents data about the structure, physical and chemical properties of iron sulfides, the mechanism of their oxidation, their uses and their environmental implications. The iron sulfides are classified as iron monosulfides (pyrrhotite, troilite and mackinawite) and iron disulfides (pyrite and marcasite).
\end{abstract}

Keywords: pyrrhotite, troilite, mackinawite, pyrite, marcasite

\section{INTRODUCTION}

Iron sulfides are common in nature, being the most frequent of the mineral sulfides. They are formed in oxygen-deficient environments and they are the main mineral sulfides responsible for the acidic waters in the mining areas.

DOI: 10.52846/AUCCHEM.2021.2.09 
When they are extracted from the ground and come into contact with oxygen-bearing water or air, iron sulfides undergo an oxidative dissolution reaction.

Along with other minerals, they create environmental problems, such as acid mining drainage (AMD), a phenomenon characterized mainly by the presence of large amounts of toxic species of $\mathrm{Cd}, \mathrm{Cu}, \mathrm{Hg}$ or As in the water resulting from mining spills.

The oxidative dissolution of iron sulfides is complex and involves a kinetics and a mechanism depending on countless factors, such as: temperature, $\mathrm{pH}$ or oxidant concentration.

The aim of this paper is to collect and present the main chemical and physical properties of the most important iron sulfide phases. There are two kind of iron sulfides (Figure 1): iron monosulfides ( $\mathrm{Fe}_{\mathrm{y}} \mathrm{S} ; \mathrm{y}$ between 0.875 and 1 ) and iron disulfides $\left(\mathrm{FeS}_{2}\right)$.

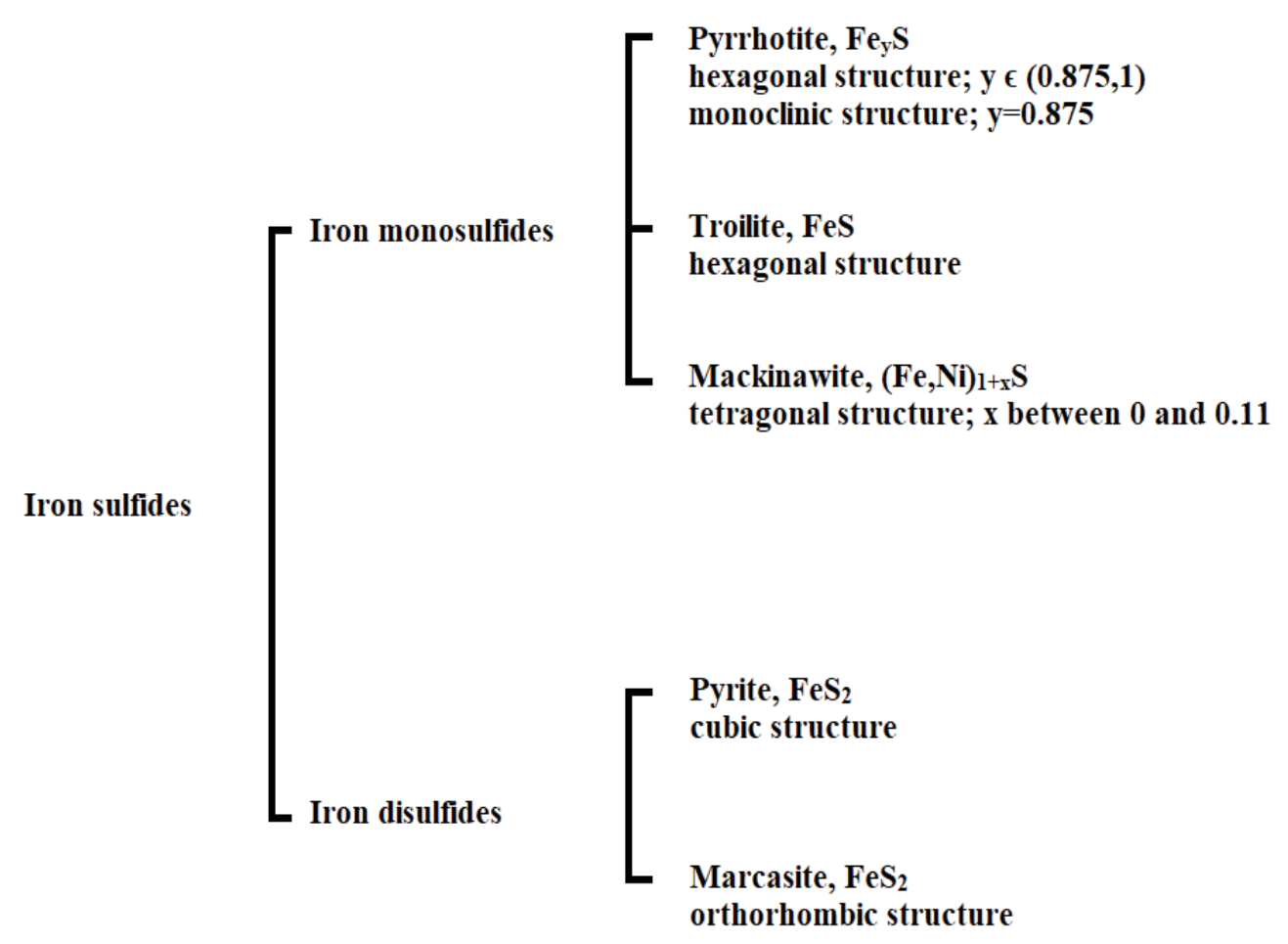

Figure 1. Iron sulfides 


\section{IRON MONOSULFIDES}

Among the iron monosulfides we can mention: pyrrhotite (FeyS; $\mathrm{y} \in(0.875,1))$, troilite $(\mathrm{FeS})$ and mackinawite $\left((\mathrm{Fe}, \mathrm{Ni})_{1+\times S}\right)$.

\subsection{Pyrrhotite}

Pyrrhotite $\left(\mathrm{Fe}_{1-x \mathrm{~S}}, 0<\mathrm{x} \leq 0.125\right)$ is one of the main iron sulfide phases that occur in reducing and anoxic environments. Unlike the dissolution of pyrite (an iron disulfide), the dissolution of pyrrhotite has been little studied. In contrast to pyrite, pyrrhotite can suffer not only oxidative dissolution but also non-oxidative dissolution. Non-oxidative dissolution takes place in several stages, including reductive and oxidative stages. The mechanism, reaction products and reaction intermediates for the dissolution of pyrrhotite are still under investigation $[1,2]$.

Non-oxidative dissolution of pyrrhotite

This process can be represented by the overall reaction:

$\mathrm{Fe}_{1-\mathrm{x}} \mathrm{S}+2 \mathrm{H}^{+}=(1-3 \mathrm{x}) \mathrm{Fe}^{2+}+2 \mathrm{xFe}^{3+}+\mathrm{H}_{2} \mathrm{~S}$

Oxidative dissolution and disproportion of pyrrhotite

All oxidative reactions of pyrrhotite dissolution can be schematized as follows:

$$
\mathrm{aFe}{ }_{1-\mathrm{x}} \mathrm{S}+\mathrm{bOx}+\mathrm{cH}_{2} \mathrm{O}=\mathrm{dFe}^{2-}+\mathrm{eH}_{\mathrm{z}} \mathrm{S}_{\mathrm{x}} \mathrm{O}_{\mathrm{y}} \mathrm{p}^{-}+\mathrm{fH}^{+}
$$

Ox represent the oxidant species and $a, b, c, d$, e and $f$ are the stoechiometric coefficients of reactants and products [1].

\subsection{Troilite}

Troilite (FeS) is a rare iron sulfide phase and a member of the pyrrhotite group. Although it can be found on Terra, it is more abundant in meteorites. FeS is commonly observed in gray brown or bronze brown colors. Troilite is opaque and non-fluorescent with metallic luster, and has magnetic properties. Its relative hardness varies from 3.5 to 4 , and the average density of troilite is $4.61 \mathrm{~g} / \mathrm{cm}^{3}$ [3]. 
Most FeS on Terra is of meteoritic origin. Troilite is the most frequent sulfide mineral on the surface of Moon. It forms about $1 \%$ of the lunar crust and is present in any rock or meteorite coming from Moon [4]. In addition, $\mathrm{FeS}$ is commonly found in meteorites originating from Mars. Similar to the surface of Moon and meteorites coming from Moon, the fraction of $\mathrm{FeS}$ in meteorites originating from Mars is close to $1 \%[4]$.

\section{Oxidation of troilite}

Dissolution of an iron monosulfide phase, such as troilite, can be non-oxidative (if the oxidation states of the elements are identical in both solution and solid phase) or can be oxidative when sulfur and/or iron in solution have a higher oxidation states than in solid.

Partial oxidation of troilite results in elemental sulfur, $S(0)$, and divalent iron, Fe(II). During oxidation with oxygen, the surface of the troilite is enriched in sulfur. The accumulation of sulfur on the troilite surface is the result of the formation of $S(0)$ and various polysulfide ions.

$\mathrm{Fe}(\mathrm{III})$ can also appear on the surface of troilite and it precipitates at a $\mathrm{pH}>3$. Troilite is unstable at $\mathrm{pH}<5$. The main product of its dissolution in anoxic medium is $\mathrm{H}_{2} \mathrm{~S}$. In an alkaline solution, $\mathrm{Fe}(\mathrm{II})$ can be further oxidized to Fe(III) with aqueous oxygen or other oxidants, and the resulted Fe(III) hydroxides can also be useful for removing heavy metals.

\subsection{Mackinawite}

Mackinawite is a nickel iron sulfide mineral $\left((\mathrm{Fe}, \mathrm{Ni}){ }_{1+x} \mathrm{~S}\right.$, with $\mathrm{x}$ between 0 and 0.11). It appears as bronze to white grey crystals. This is found in reducing environments (such river sediments) and is most probable generated by the action of sulfate-reducing microorganisms. Mackinawite is also known as tetragonal iron sulfide due to its tetragonal structure [5].

Mackinawite can be suddenly formed at temperatures under $100{ }^{\circ} \mathrm{C}$ during acidic corrosion. The presence of mackinawite is very important in the field of natural gas and refinery facilities. For example, the presence of mackinawite films together with other compounds such 
as hydrogen sulfide $\left(\mathrm{H}_{2} \mathrm{~S}\right)$ and carbon dioxide $\left(\mathrm{CO}_{2}\right)$ can promote the corrosion of carbon steel. Till now, $\mathrm{H}_{2} \mathrm{~S}$ corrosion did not caused much interest, which is in opposition to the well-known $\mathrm{CO}_{2}$ corrosion, which has a well-understood reaction mechanism. Nevertheless, it was observed that $\mathrm{H}_{2} \mathrm{~S}$ corrosion in carbon and iron steel can occur after the adsorption of $\mathrm{H}_{2} \mathrm{~S}$ on the surface of the material where a mackinawite film can form in a specific way [5,6].

In sedimentary environments mackinawite is relatively soluble having a minimum solubility in neutral to alkaline media. In these media, its solubility is controlled by FeS aq whereas in more acid environments it is in equilibrium with the $\mathrm{Fe}(\mathrm{II})$ and $\mathrm{S}(-\mathrm{II})$. The mackinawite dissolution rate is high, with a first order dependence on $\left[\mathrm{H}^{+}\right]$, in acid solutions, and zero order dependence on $\left[\mathrm{H}^{+}\right]$in neutral to alkaline solutions; this being in accordance with the solubility. Far from equilibrium, the dissolution rate of $\mathrm{FeS}_{\mathrm{m}}$ in sediments is $10^{-4} \mathrm{~mol} \mathrm{~s}^{-1}$ [6].

Mackinawite was not often observed in ordinary marine sediments. Majority of observations are in systems with high total concentration of $\mathrm{Fe}(\mathrm{II})$. Instead, the $\mathrm{FeS}_{\mathrm{aq}}$ cluster has been frequently observed, observations which are consistent with the solubility data [6].

\section{IRON DISULFIDES}

There are two iron disulfides $\left(\mathrm{FeS}_{2}\right)$ : pyrite and marcasite.

\subsection{Pyrite}

Pyrite is the most abundant metal sulfide in the crust of the Earth. It is found in hydrothermal deposits, igneous rocks, and sedimentary beds. Natural pyrite contains many impurities, such as $\mathrm{Ag}, \mathrm{Au}, \mathrm{Cd}, \mathrm{Co}, \mathrm{Cu}, \mathrm{Mo}$, $\mathrm{Ni}, \mathrm{Pb}, \mathrm{Zn}, \mathrm{Sn}, \mathrm{Se}, \mathrm{Sb}$, and Te. Pyrite oxidation usually releases the impurities incorporated in its structure. Pyrite oxidation involves water and an oxidant (oxygen, ferric iron, hydrogen peroxide etc.), the reaction product, the sulfuric acid, subsequently producing acid mine drainage. AMD is a long-term environmental issue, which affects the environment through the acidification of aquifers, and mobilization of heavy metals [7]. 
Pyrite has the chemical formula $\mathrm{FeS}_{2}$, meaning that it is made of one iron atom $(\mathrm{Fe})$ and two sulfur atoms $\left(\mathrm{S}_{2}\right)$. These atoms are arranged to form a cubic structure. Pyrite can adopt various forms of crystal, including a perfect cube (unique to pyrite) or pyritohedrons (a twelvesided shape named after the mineral) [8].

One ordinary way of forming pyrite is in a deep marine setting after the deposition of organic-rich sediments. Bacteria decompose the organic compounds and form disulfide, the sulfur component of pyrite. Disulfide reacts with divalent iron forming pyrite. It is interesting to mention that, this process can appear in fossils being preserved as $\mathrm{FeS}_{2}$ when the mineral replaces the decomposing organic material preserving the original shape of the fossil. This is a reaction called pyritisation [8].

Pyrite is used commercially in the production of sulfuric acid and sulfur dioxide [8].

\subsubsection{Oxidation of pyrite}

It has already been said that the dissolution of pyrite takes place exclusively by oxidation. Oxidation of pyrite has been studied in recent years because this reaction of $\mathrm{FeS}_{2}$ helps to extract valuable metals from pyrite deposits. $\mathrm{FeS}_{2}$ oxidation is important to understand the formation of sulfuric acid, it being the main component of AMD. The oxidation mechanism of pyrite is not fully understood because the reported results and conclusions are not always consistent with the idealized oxidation mechanism and reaction kinetics. During the oxidation several intermediates and products are formed for example $\mathrm{S}_{2} \mathrm{O}_{3}{ }^{2-}, \mathrm{S}^{0}, \mathrm{~S}_{8}$, $\mathrm{HSO}_{4}^{-} \mathrm{Fe}_{2} \mathrm{O}_{3}$ or $\mathrm{Fe}(\mathrm{OH})_{3}$. It is important to investigate the surface oxidation of pyrite to find its oxidation mechanism and to find the ways to control the source of AMD [7].

According to the literature, pyrite oxidation has been previously identified to involve thiosulfate as the first aqueous intermediate sulfur product, which is further oxidized to sulfate [9]. Jiling Feng and his collaborators [7] studied the directional oxidation rate and the surface morphologies of the pyrite. They used Raman spectroscopy and X-ray photoelectron spectroscopy (XPS) to detect the oxidation products formed at pyrite surface. Oxidation in acid solution was conducted at 
room temperature. The pyrite samples were placed in a mixture of 250 $\mathrm{mL}$ of $1 \mathrm{M} \mathrm{H}_{2} \mathrm{SO}_{4}$ and $10 \mathrm{~mL}$ of $9.9 \mathrm{M} \mathrm{H}_{2} \mathrm{O}_{2}$. FeS 2 samples were oxidized for four or eight days. The samples were removed and were washed with deionized water and ethanol at certain interval and dried at room temperature. The morphological changes of the samples were monitored, the surface composition was analyzed, the depth and volume of the etching pits formed on the pyrite surfaces were measured and the concentration of total iron ions $\left(\mathrm{Fe}^{3+}\right.$ and $\left.\mathrm{Fe}^{2+}\right)$ was determined [7]. It was observed that the surface of the oxidized pyrite sample is flat and smooth. The elements present on the pyrite surface are Fe (45.79\%) and S (54.21\%) [7]. Total ion concentrations were measured in different directions of the crystal. It is considered that, the observed arrangement of the atomic surface is important for the physical and chemical behavior of pyrite. On the basis of the Raman spectroscopy and XPS analysis, are proposed the following reactions [7]:

$\mathrm{FeS}_{2}+3.5 \mathrm{O}_{2}+\mathrm{H}_{2} \mathrm{O} \rightarrow \mathrm{Fe}^{2+}+2 \mathrm{SO}_{4}{ }^{2-}+2 \mathrm{H}^{+}$

$\mathrm{Fe}^{2+}+3 \mathrm{H}_{2} \mathrm{O} \rightarrow \mathrm{Fe}(\mathrm{OH})_{3}+3 \mathrm{H}^{+}+\mathrm{e}^{-}$

$\mathrm{FeS}_{2} \rightarrow \mathrm{Fe}^{2+}+2 \mathrm{~S}(0)+2 \mathrm{e}^{-}$

$\mathrm{FeS}_{2} \rightarrow \mathrm{Fe}^{3+}+2 \mathrm{~S}(0)+3 \mathrm{e}^{-}$

$2 \mathrm{Fe}^{3+}+3 \mathrm{H}_{2} \mathrm{O} \rightarrow \mathrm{Fe}_{2} \mathrm{O}_{3}+6 \mathrm{H}^{+}$

\subsubsection{Electronic properties of pyrite}

The electronic properties of pyrite have received special attention. Unfortunately, there is still a lack of information and direct evidences about how impurity elements affect mineral semiconductor properties. It is known that, pyrite containing arsenic is a p-type semiconductor, and pyrites containing $\mathrm{Ni}, \mathrm{Co}, \mathrm{Cu}$, and other elements are n-type semiconductors. If p-type pyrites containing As are supplemented with $\mathrm{Ni}, \mathrm{Cu}$, and other elements, the semiconductor type changed to n-type. Co addition did not change the semiconductor type of As-rich pyrite. It is interesting to mention that, pyrite formed under different temperature conditions are enriched with different combinations of impurity elements, leading to the relative accumulation of p-type or ntype pyrites [10]. 


\subsubsection{Applications of pyrite}

Transition metal sulfides are of special interest in energy conversion and storage devices. Amongst all sulfides, pyrite is potentially an attractive candidate for photovoltaic applications. $\mathrm{FeS}_{2}$ is promising due to its particular properties and abundance in nature to meet the various needs. It is considered an environmentally friendly solar absorbent material with a high absorption coefficient. Pyrite is a low cost photovoltaic absorber material for contemporary solar cell structures [11]. Countless physical and chemical methods have been employed to deposit nanocrystalline pyrite thin films directly from source materials or indirectly by sulfuration.

\subsection{Marcasite}

Marcasite (the second iron disulfide) forms pale bronze-yellow crystals. Marcasite is found with lead and zinc minerals in metalliferous veins $[12,13]$. Marcasite and pyrite have the same chemical composition, but different structures. Pyrite crystallizes in the cubic system, while marcasite is orthorhombic. Marcasite is much more reactive than pyrite, and it is oxidized at a much higher rate. Marcasite will degrade easily when exposed to the weather [14]. Marcasite has a strong tendency to form with pyrite upon sulfurization of amorphous iron-oxide films, leading to a mixed-phase structure in which pyrite grains are surrounded by nanocrystalline marcasite [15].

Marcasite is widespread in nature, its oxidation plays an important role in mineral resource recovery and acid mine drainage.

Marcasite forms as a primary sedimentary mineral (as a results of low-temperature hydrothermal activity) and as a secondary mineral (forming during the degradation of other sulfides). Marcasite formation occurs at relatively low temperatures and elevated acidity. Marcasite can appear in organic-rich clays and peats in course of their sedimentation or in course of diagenesis [14].

Marcasite has an economic importance when it appears in coal. It contributes to the sulfur dioxide emissions during the burning of coal. Marcasite has been used in the past as a minor source of sulfur and for 
making sulfuric acid. In present days, marcasite does not have any economic significance [14].

As in the case of pyrite, marcasite is oxidized releasing ferrous iron, sulfate and protons. The effects of environmental factors on marcasite oxidation, such as [dissolved oxygen], [Fe(III)] and [Fe(II)] or $\mathrm{pH}$ have been reported by a number of authors. Few investigations have focused on the dissolution kinetics of marcasite [10].

In contrast to the oxidation of pyrite, the oxidation of marcasite only occurs at surface $S$ atoms. In the simultaneous presence of water and oxygen, $\mathrm{S}$ atoms around surface $\mathrm{Fe}$ atoms are replaced by $\mathrm{O}$ atoms. The surface $S$ sites are initially oxidized to form $S=O$ bonds, and continue to adsorb oxygen to gradually generate $\mathrm{SO}_{3}{ }^{2-}$ and $\mathrm{SO}_{4}{ }^{2-}$ ions, and eventually $\mathrm{FeSO}_{4}$. In this reaction, $\mathrm{H}_{2} \mathrm{O}$ molecules take part in neither oxidation nor dissociation, and they are just adsorbed in the molecular form on surface Fe sites, all $\mathrm{O}$ atoms in $\mathrm{SO}_{4}{ }^{2-}$ coming from oxygen rather than water molecules [16].

When marcasite is in moist air, some ferrous sulfate will appear on surface [16]:

$\mathrm{FeS}_{2}($ marcasite $)+\mathrm{H}_{2} \mathrm{O}+7 / 2 \mathrm{O}_{2} \rightarrow\left(\mathrm{Fe}^{2+}+\mathrm{SO}_{4}{ }^{2-}\right)+\mathrm{SO}_{4}{ }^{2-}+2 \mathrm{H}^{+}$

\section{IMPLICATIONS OF IRON SULFIDES OXIDATION ON THE ENVIRONMENT. ACID MINE DRAINAGE (AMD)}

Acid mining drainage (AMD) is a phenomenon that occurs as a result of the oxidative dissolution of mineral sulfides in the mine dumps, when they come into contact with oxygen-bearing water and microorganisms. This phenomenon is characterized by water contamination with $\mathrm{H}_{2} \mathrm{SO}_{4}$ and $\mathrm{Cu}, \mathrm{Pb}, \mathrm{Cd}, \mathrm{Hg}$ or As ions. Iron sulfides, being the most widespread of the mineral sulfides, are the main mineral sulfides responsible for AMD in the areas where mining is practiced. The contaminated water at surface and in ground causes severe imbalances in the food chain, in some cases meaning the disappearance of aquatic life in the affected area. 


\section{REFERENCES}

1. P. Chiriţă and M. Descostes, An. Univ. Craiova Chem. Ser., 32 (2003) 69.

2. P. Chirita and M. Descostes, J. Colloid Interface Sci., 299 (2006) 260.

3. https://www.azomining.com/Article.aspx?ArticleID=299

4. https://en.wikipedia.org/wiki/Troilite

5. https://www.corrosionpedia.com/definition/1537/mackinawite

6. https://doi.org/10.1016/B978-0-444-52989-3.00006-4

7. https://doi.org/10.3390/min9010007

8. https://www.birmingham.ac.uk/facilities/lapworth-museum/about/object-pyrite.aspx

9. https://doi.org/10.3389/fmicb.2018.03134

10. https://doi.org/10.3390/min11060596

11. https://doi.org/10.1002/slct.201800405

12. http://www.webmineral.com

13. https://www.britannica.com/science/marcasite

14. https://geology.com/minerals/marcasite.shtml

15. https://doi.org/10.1016/j.solener.2017.11.026

16. https://doi.org/10.1016/j.ijmst.2021.11.012 